\title{
ACUTE DACRYOADENITIS ASSOCIATED WITH INFECTIOUS MONONUCLEOSIS
}

\author{
Marija Cvetanović1 ${ }^{1}$ Aleksandar Veselinović ${ }^{1}$, Marija Trenkić-Božinović ${ }^{1}$, \\ Kristina Stojanović ${ }^{2}$, Ivona Trajković ${ }^{2}$, Dragan Veselinović ${ }^{1}$
}

\begin{abstract}
The paper presents a case report of a patient with unilateral acute dacryoadenitis caused by infectious mononucleosis. The aim of the paper was to point out therapeutic and diagnostic possibilities in patients with dacryoadenitis.

Hyposecretion of tears was determined by Schirmer's test. MRI revealed lacrimal gland enlargement with signs of inflammation in the surrounding orbital tissue. Laboratory tests for Epstein Barr virus infection were positive.

Clinical manifestation of infectious mononucleosis was proved by a pediatrician.

The application of local and general therapy resulted in withdrawal of the lacrimal gland enlargement, stabilization of inflammation symptoms and normalization of a grey eye in our patient.

Acute dacryoadenitis is a relatively rare pathological condition requiring appropriate diagnostics for proper treatment, as it was the case with our patient in whom infectious mononucleosis caused the disease.
\end{abstract}

Acta Medica Medianae 2020;59(1):149-152.

Key words: dacryoadenitis, infectious mononucleosis

${ }^{1}$ Ophthalmology Clinic, Clinical Center Niš, Serbia

${ }^{2}$ Ophthalmology Surgery Veselinović Zone of Vision Niš, Serbia

Contact: Marija Cvetanović

48 Dr. Zoran Djindjić Blvd., 18000 Niš, Serbia

E-mail: marija.cvetanovic@gmail.com

\section{Introduction}

The frequency of dacryoadenitis is low; it occurs in only one case per 10,000 ophthalmic patients. There is no predilection for race, gender or age for the onset of the disease. Dacryoadenitis can be acute or chronic $(1,2,3)$.

Acute dacryoadenitis is usually unilateral and characterized by painful swelling of the eyelid with the signs of chemosis, conjunctival hyperemia, erythema of the lids and lymphadenopathy (submandibular). Its characteristic features include swelling of the outer third of the lid, proptosis, occasionally ocular motility restriction and painful globe movement $(1,2)$.

It is commonly an independent disease (viral, bacterial infections) with good prognosis. Factors that may cause acute dacryoadenitis are mostly due to infections with viral etiologies (mumps, EpsteinBarr virus, herpes zoster virus), or bacterial etiologies caused by staphylococcus, streptococcus, haemophilus influenza, gonorrhea or chlamydia. Infection may spread to the lacrimal gland hematogenously, transneuronally, from the inflamed conjunctiva or via traumatic injuries $(4,5,6,7)$.

Chronic dacryoadenitis is usually bilateral and painless with minimal ocular signs. Chronic condition is accompanied by enlargement of the lacrimal gland present for months $(8,9,10)$.

It is usually associated with a systemic disease (sarcoidosis, tuberculosis, Mikulicz's syndrome, Sjogren's syndrome, syphilis, leukemia). Prognosis depends on the underlying cause of the systemic disease. Symptoms of mild to severe dry eyes are also present $(11,12,13)$.

\section{Case study}

A girl aged 14 presented to her doctor with the complaints of pain and swelling of her right outer upper eyelid.

The local finding revealed the absence of tarsal and bulbar conjunctival inflammation, enlarged right lacrimal gland with the signs of inflammation and edema in that region. Mild proptosis and upper lid swelling were present in the outer part with characteristic "comma-like" appearance (Figure 1). The outer upper portion of the eyelid was painful on palpation, and the patient reported the feeling of 
scratching and dryness in the right eye, as well as pain on the right eye movement. Schirmer's test registered hyposecretion of tears in the right eye, while the finding of the left eye was within the reference range (Figure 2 ).

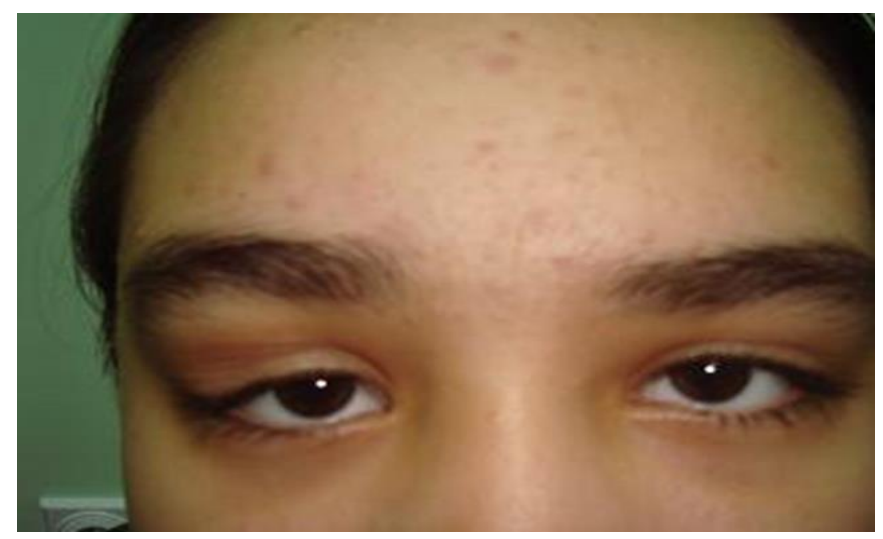

Figure 1. Acute dacryoadenitis of the right eye

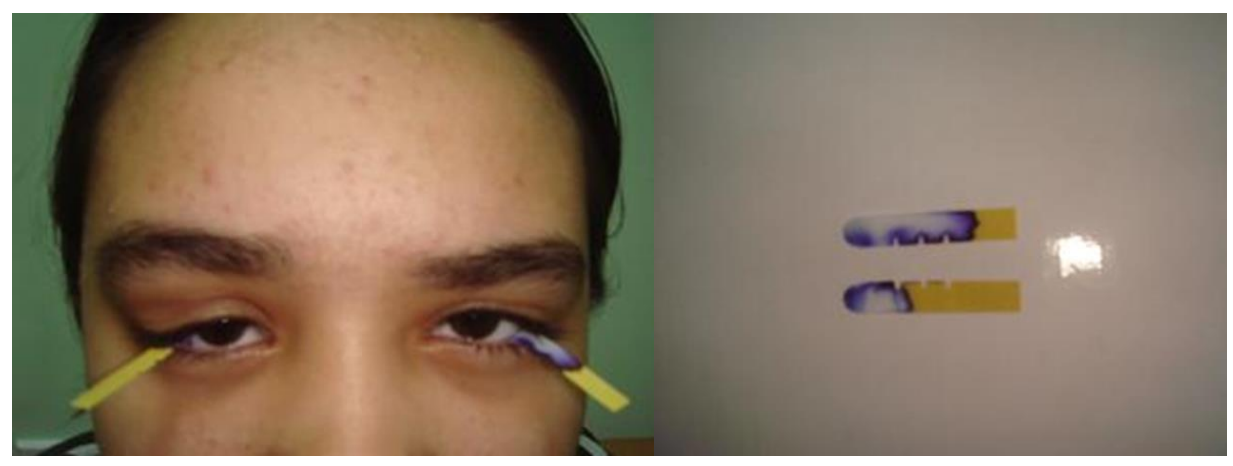

Figure 2. Shirmer's test

Magnetic resonance imaging showed enlarged lacrimal glands with the signs of inflammation in the surrounding orbital tissue. Laboratory findings were positive for Epstein Barr virus.

The presence of infectious mononucleosis was confirmed by a pediatrician based on clinical examination and laboratory finding. After the consultation with a pediatrician, systemic corticosteroids (40 mg Lemod Solu) for five days and local corticosteroid therapy in the form of drops and ointments were administered, resulting in the reduction of inflammation signs in the area of the lacrimal gland and in disappearance of the general symptoms of the disease. The girl did not show up for further controls, so the control check-up to prove the normalization of tear secretion in the eye with dacryoadenitis was not possible.

\section{Discussion}

Acute dacryoadenitis has a characteristic clinical manifestation and can easily be identified (1, 150
2). It is most commonly unilateral, but in rare cases it can be a bilateral disease (10). This relatively rare lacrimal gland disorder requires determination of the causative agents as early as possible for timely and adequate therapy. One of the common causes of dacryoadenitis can be an infection caused by Epstein Barr virus within infectious mononucleosis. Infectious mononucleosis occurs sporadically and primarily affects young adults, but it can also affect people of any age. Infectious mononucleosis is an acute disease caused by a virus that most commonly infects the liver and lymphoid tissue $(13,14)$. Clinical manifestations of the disease include fatigue, muscle pain, increase in body temperature and headache. Within the disease, the liver and spleen are enlarged with accompanying symptoms. The disease commonly has benign course and the symptoms withdraw after two weeks.

The signs of dacryoadenitis are common presentation in patients with infectious mononucleosis. In a study of 16 patients with dacryoadenitis there were 6 patients with the signs of infectious mononucleosis and serological testing positive for Epstein- 
Barr virus infection (3). Acute dacryoadenitis caused by Epstein-Barr virus most commonly occurs in younger population, rarely in elderly people $(1,2)$. In our patient characteristic symptoms were manifested unilaterally. Hyposecretion of tears in the affected eye was associated with other symptoms of the disease.

\section{Conclusion}

Acute dacryoadenitis can often be associated with infectious mononucleosis and it can be manifested in children and young adults. Upon the con- firmation of the presence of infectious mononucleosis a pediatrician and an infectologist should be consulted for appropriate therapy. Despite the fact that some authors support conservative treatment, administration of general corticosteroid therapy speeds up the recovery of general symptoms in these patients and local symptoms of dacryoadenitis as well. Hyposecretion of tears in dacryoadenitis may be a characteristic symptom of the disease. It disappears with the treatment and the loss of inflammatory signs.

\section{References}

1. Aburn NS, Sullivan TJ. Infectious mononucleosis presenting with dacryoadenitis. Ophthalmology 1996; 103(5):776-8. [CrossRef] [PubMed]

2. Rai $P$, Shah SA, Kirshan H. Acute Dacryadenitisanalysis of 23 cases. Med Channel 2009;15:71-6.

3. Rhem MN, Wilhelmus KR, Jones DB. Epstein-Barr virus dacryoadenitis. Am J Ophthalmol 2000;129(3):372-5. [CrossRef] [PubMed]

4. Srivastava VK. Acute Suppurative Dacryoadenitis. Medical Journal Armed Forces India 2000;56:151-2. [CrossRef] [PubMed]

5. Goold LA, Madge SN, Au A, Leibovitch I, McNab A, Tumuluri $K$, et al. Acute suppurative bacterial dacryoadenitis: a case series. $\mathrm{Br} \mathrm{J}$ Ophthalmol 2013;97(6):735-8. [CrossRef] [PubMed]

6. Hartikainen J, Lehtonen OP, Saari M. Bacteriology of lacrimal duct obstruction in adults. $\mathrm{Br} \mathrm{J}$ Ophthalmol 1997;81:37-40. [CrossRef] [PubMed]

7. Kubal A, Garibaldi DC. Dacryoadenitis caused by methicillin-resistant Staphylococcus aureus. Ophthal Plast Reconstr Surg 2008;24(1):50-1. [CrossRef] [PubMed]

8. Derr C, Shah A. Bilateral dacryoadenitis. J Emerg Trauma Shock 2012;5(1):92-4. [CrossRef] [PubMed]
9. Baoke H, Shihui W, Maonian Z, Zhaohui L, Zhitong Z, Zhigang $S$, et al. Bilateral dacryoadenitis complicated by lymphocytic hypophysitis. J Neuroophthalmol 2009; 29:214-8. [CrossRef] [PubMed]

10. Moscovici BK, Romero IL, Vital Filho J, Bison SH. Epstein-Barr virus bilateral dacryoadenitis: case report. Arq Bras Oftalmol 2009;72(6):826-8. [CrossRef] [PubMed]

11. Dutt S, Cartwright MJ, Nelson CC. Acute dacryoadenitis and Crohn's disease: findings and management. Ophthal Plast Reconstr Surg 1992;8(4):295-9. [CrossRef] [PubMed]

12. Nieto JC, Kim N, Lucarelli MJ. Dacryoadenitis and orbital myositis associated with lyme disease. Arch Ophthalmol 2008;126(8):1165-6. [CrossRef] [PubMed]

13. Bailey RE. Diagnosis and treatment of infectious mononucleosis. Am Fam Physician 1994;49:879-88. [PubMed]

14. Mark H. Ebell. Epstein-Barr Virus Infectious Mononucleosis. Am Fam Physician 2004;70(7):1279-87. [PubMed] 


\title{
AKUTNI DAKRIOADENITIS UDRUŽEN SA INFEKTIVNOM MONONUKLEOZOM
}

\author{
Marija Cvetanović ${ }^{1}$, Aleksandar Veselinović ${ }^{1}$, Marija Trenkić-Božinović ${ }^{1}$, \\ Kristina Stojanović ${ }^{2}$, Ivona Trajković ${ }^{2}$, Dragan Veselinović ${ }^{1}$
}

${ }^{1}$ Klinika za očne bolesti, Klinički centar Niš, Niš, Srbija

¿Ordinacija za očne bolesti „Zona vida Veselinović", Niš, Srbija

Kontakt: Marija Cvetanović

Bulevar dr Zoran Đinđić 48, 18000 Nišs, Srbija

E-mail: marija.cvetanovic@gmail.com

U radu je dat prikaz bolesnika sa jednostranim akutnim dakrioadenitisom prouzrokovanim infektivnom mononukleozom. Cilj rada je da se ukaže na terapijske i dijagnostičke mogućnosti kod bolesnika sa dakrioadenitisom.

Hiposekrecija suza dokazana je Schirmerovim testom. MR pokazala je uvećanje suzne žlezde sa znacima inflamacije okolnog orbitalnog tkiva. Registrovani su pozitivni laboratorijski nalazi na Epstein-Barr virus.

Od strane pedijatra, potvrđena je klinička slika infektivne momonukleoze.

Na primenu lokalne i opšte terapije došlo je do povlačenja otoka suzne žlezde, smirivanja simptoma inflamacije i normalizovanja simptoma sivog oka kod bolesnika.

Akutni dakrioadenitis je relativno retko patološko stanje i zahteva odgovarajuću dijagnostiku, nakon koje je olakšana terapija, što se pokazalo i u slučaju našeg bolesnika, kod kojeg je bolest bila prouzrokovana infektivnom mononukleozom.

Acta Medica Medianae 2020;59(1):149-152.

Ključne reči: dakrioadenitis, infektivna mononukleoza 